\title{
Contemporary Light Vaults in Colombia. The origin of a modern tradition
}

\author{
Julián García \& Fernando Magdalena \\ Universidad Politécnica. Madrid. Spain \\ Juan M. Medina \\ Universidad de los Andes. Bogotá. Colombia
}

\begin{abstract}
Le Corbusier designed tile vaults for the structures of several buildings in the 1950s, yet he only built two: the ones in the Maisons Sarabhai (Ahmadabad 1955) and Jaoul (Paris 1955). Le Corbusier's vaults were later very influential, mainly in Latin America, where they became the inspiration for numerous buildings in the middle decades of the 20th century. However, little is known about the fact that the main inspiration for Le Corbusier's vaults is a demolished Colombian building, the home of local architect Francisco Pizano de Brigard.

The Casa Pizano was just one of the many modern Latin American vaulted houses built in those years some of them using tile vaults. Many of these constructions were previous to the ones raised by Le Corbusier, so it seems only logical to think that the Maisons Sarabhai and Jaoul had a lesser influence on local architects and builders. The hypothesis of this paper is that, although this influence existed, local networks were essential in the task of connecting similar technical initiatives. To verify this hypothesis, several examples of buildings from different Latin American countries, starting from the Casa Pizano, will be studied, and some possible contacts between architects will be proposed.
\end{abstract}

\section{LE CORBUSIER AND THE CASA PIZANO}

Le Corbusier knew about tile vault construction at least since 1928. The sketches he drew in notebook C11, about the roof of the schools of the Sagrada Familia, (A. Gaudí, 1909) show that he was interested not only in the peculiar geometrical configuration of the building, but also in the systems used in its construction. It is probable, moreover, that he knew about the construction and structural behaviour of these vaults by other Spanish architects with whom he collaborated, such as José Luis Sert, who used them in his Casas Garraf (1935), or Antonio Bonet, who experimented with them at the wellknown Casas Berlingieri (1947) or Ricarda (1953) (Tomlow 1999; López 2015).

However, it was not this experience what led him to use his particular version of the tile vault in two projects of great influence, the Maisons Sarabhai (Ahmadabad 1955) and Jaoul (Paris 1955). In academic circles it is commonly accepted (Gulli 1999) that the most immediate influence for these vaults was the then newly built house of the local architect Francisco Pizano de Brigard, that Le Corbusier discovered in his travels to Bogotá in the 1950s.

Unfortunately the Casa Pizano does not exist anymore. However, its architectural and constructive configuration are well known. The building, with a plant in L, consisted of three main areas separated by loadbearing walls, the longest of them of double height (Fig. 1). All the horizontal structures were segmental vaults, with a span/rise ratio of approximately $1 / 8$, built with traditional tile vault construction techniques, with two brick layers (Figs 2A and 2B). They were finished on the outside with a layer of waterproof mortar. The vaults rested on concrete edge beams, cable-stayed (only in the lateral bays, as for the central bay the cables were logically considered unnecessary) by means of steel tension rods to alleviate the thrust of the masonry vaults. The details of the materials and the construction processes are not well known, except for the sketches made by Le Corbusier (Figs 3A and 3B) which are not too precise -they only include 2 centimetres thick tiles, but maybe a ‘tablón' brick (a hollow ceramic 6 centimetres thick piece, similar to the one that was later prescribed for the Casa Bermúdez-Samper project) and a conventional sliding formwork were used. Rodriguez points out that, although "racillas" (a thin slab of $25 \times 12 \times 2 \mathrm{~cm}$ ) could have been used in the staircase, the main vault was made with larger pieces, as described by Pizano: "That it is what the drawing says and I do not have how to distort it; I do not know what the dimensions of the brick would exactly be, but surely it was something similar to the current standard of 24x12x6 "(Rodríguez 2008). 

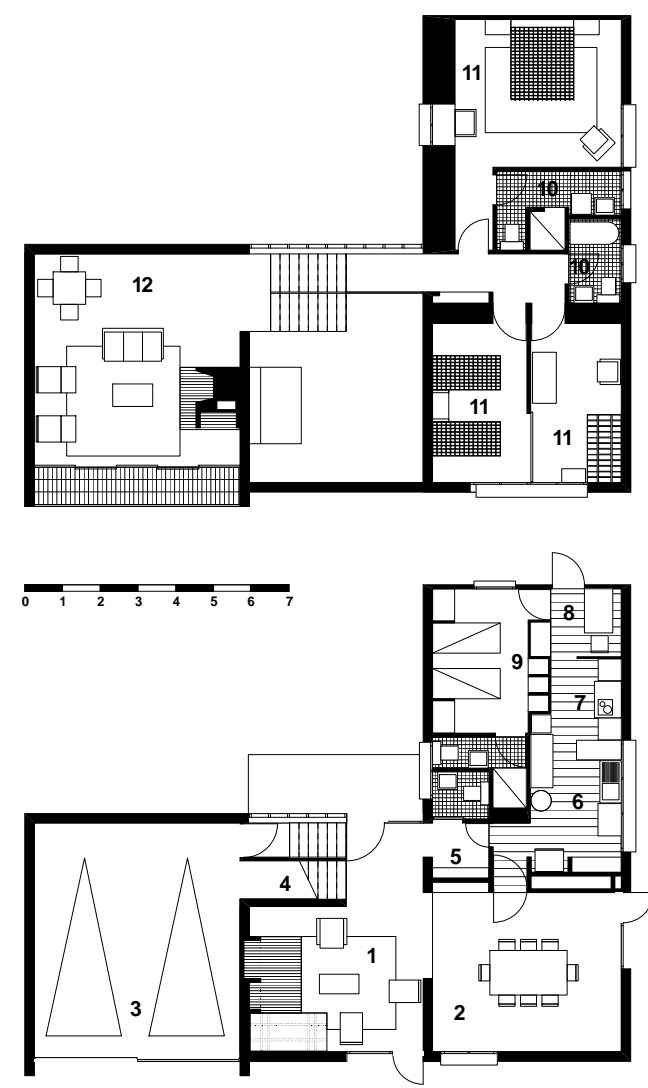

Figure 1. Casa Pizano (Pizano 1950). Low level and first floor.

The construction of tile vaults, a traditional Mediterranean system, was unusual in Bogotá - although all over the country modern vaulted buildings were being made using other techniques, such as reinforced ceramics or lightweight concrete. Unlike other areas of Latin America, Colombia has no record of vaulted systems in vernacular construction (Corradine 2001, Arango 1989), and illustrious precedents (such as the vaults of the Bogota Astronomical Observatory staircase, by Fray Domingo de Petrés) (Torres 2012) are scarce. The most plausible reason for the use of tile vaults in the construction of the Casa Pizano was the close relationship of Pizano with an architect and builder of Spanish origin, Fernando Murtra, who built various tile vaults in the area. J.L. Rodríguez does not doubt it: "The Catalan vault of the Casa Pizano was made this way because the architect had the help of the Catalan Fernando Murtra; even the workers who worked with him were Catalans. Without Murtra surely concrete would have been used, because at that time concrete was associated with being modern "(Rodríguez 2008).

It should be noted that Pizano, who would later use reinforced ceramics or concrete in other vaults in the Bogotá area, was fully aware of the structural behaviour of the vaults he had built in his house. In an interview that took place in 2002 (Gutiérrez) he stated: "It was then that we made several houses, among them my own first house, located in the eastern hills of Bogotá near the Nueva Granada school. This house was later demolished. In it we rehearsed, I believe that for the first time in Colombia, the modern construction of thrust brick vaults, like all the Catalan ones that all the constructions in Cartagena have. The design included three vaults and had a slender staircase inside, made of thrust tiles. Probably the house was not very practical but it was volumetrically very beautiful " (Figs 4A and 4B).
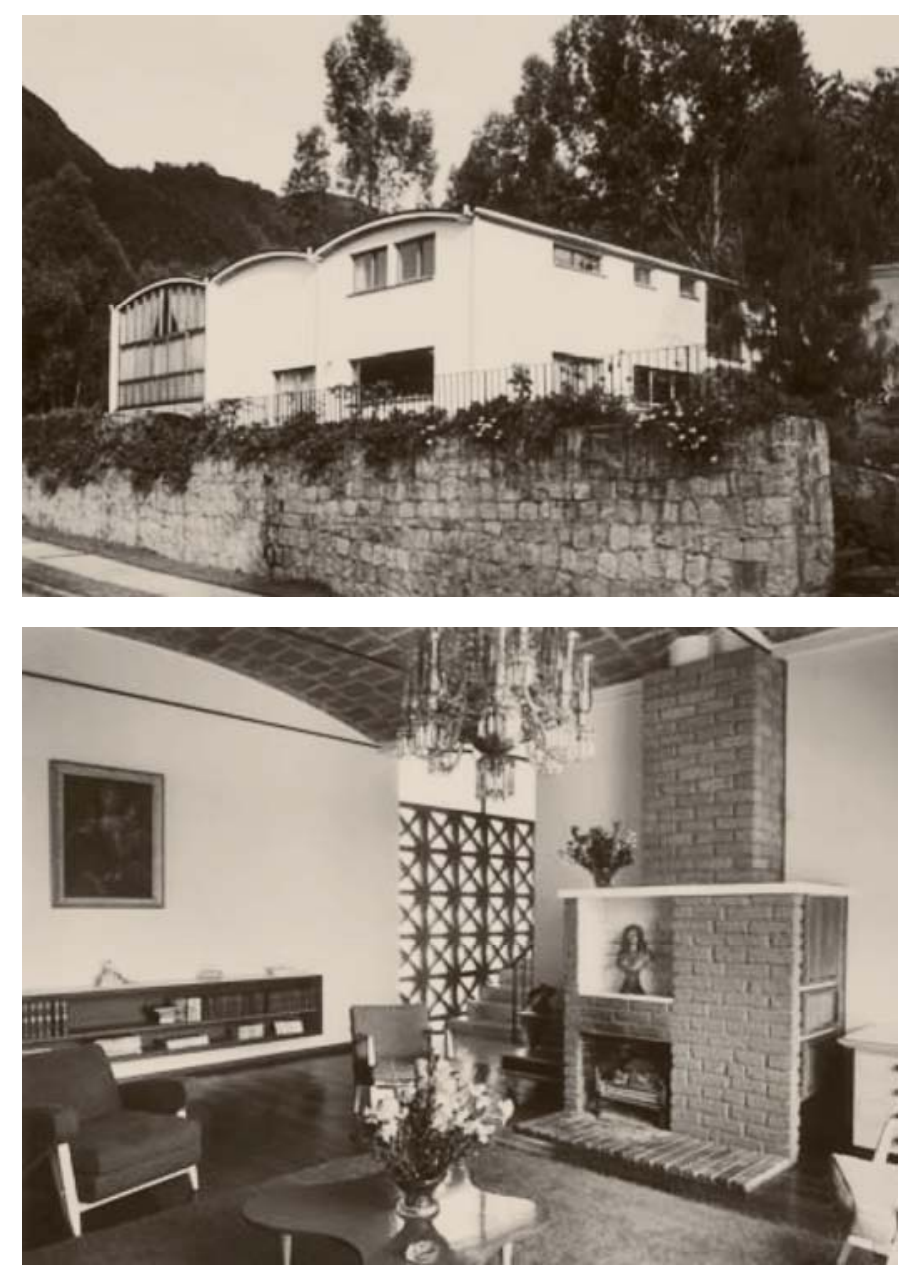

Figure 2A. General view of the Casa Pizano (Pizano 1950). Figure 2B. From PROA n ${ }^{\circ} 42$. Interior of the Casa Pizano (Pizano 1950). From Rodríguez 2008.
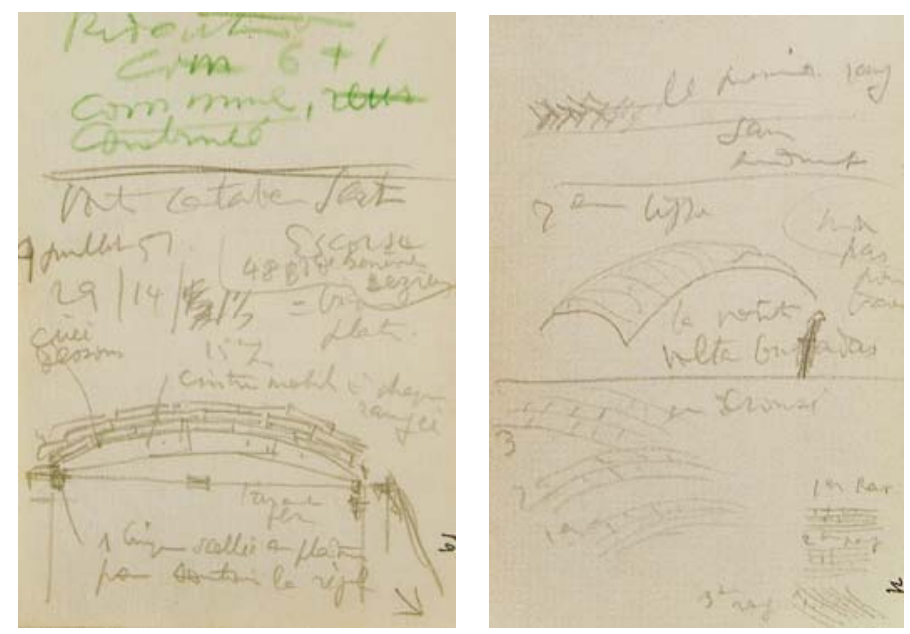

Figure 3A. Le Corbusier. Notebook E21, p.512. Figure 3B. Le Corbusier. Notebook E21, p.513. Both from Maniaque 2009.

Pizano designed tile vaults for some other projects, most unbuilt, but gradually abandoned its use. In a later interview, he clarified that the reasons for this 


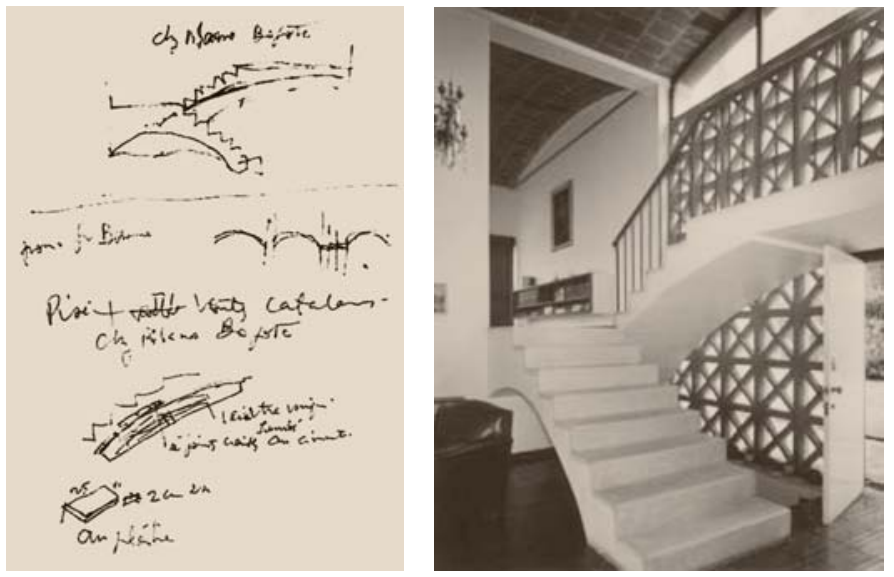

Figure 4A. Le Corbusier. Notebook D51. From Gulli 1999. Figure 4B. Interior staircase of the Casa Pizano (Pizano 1950). From Rodríguez 2008.

had not been of technical nature: "As an anecdote, and also as a self-recrimination; my current house does not have vaults because when I was dean and workshop teacher in Los Andes, I found out that the students said 'draw some vaults for Pizano and you will pass the subject!' Partly because of that I changed my mind. I regret it, not because I do not like the space of this house where I still live, but because the vaulted space is still very striking to me"(Rodríguez 2008). The first Casa Pizano did not set a local precedent in terms of the technique used (although it did set a precedent, as will be discussed later, in terms of constructive and architectural typology) and few tile vaults were used later in Colombian buildings. But in the following years several tile vaulted roofs, very similar to those used in Casa Pizano, were built in large areas of Latin America.

\section{LOCAL AND GLOBAL BACKGROUND FOR THE CASA PIZANO}

In addition to the influence of Murtra, which was probably operational rather than architectural, several buildings and previous projects could have been in Pizano's mind when designing and building his house in Bogotá. Among the best known ones is, of course, Casa Berlingieri (Bonet, calculations by Dieste, 1947), whose influence affects all the constructions studied in this article. The fact that this building is conventionally considered the first one covered with reinforced ceramics (Tomlow 1999) dilutes the importance of its architectural proposal and its influence on later buildings. The relationship between this construction and the work of Le Corbusier has been sufficiently studied (Arnaldos 2014); it has not been proved that that Pizano knew it, although it seems evident that he had knowledge of other similar constructions, previous or subsequent to the Berlingieri. Some of the main ones are listed below.
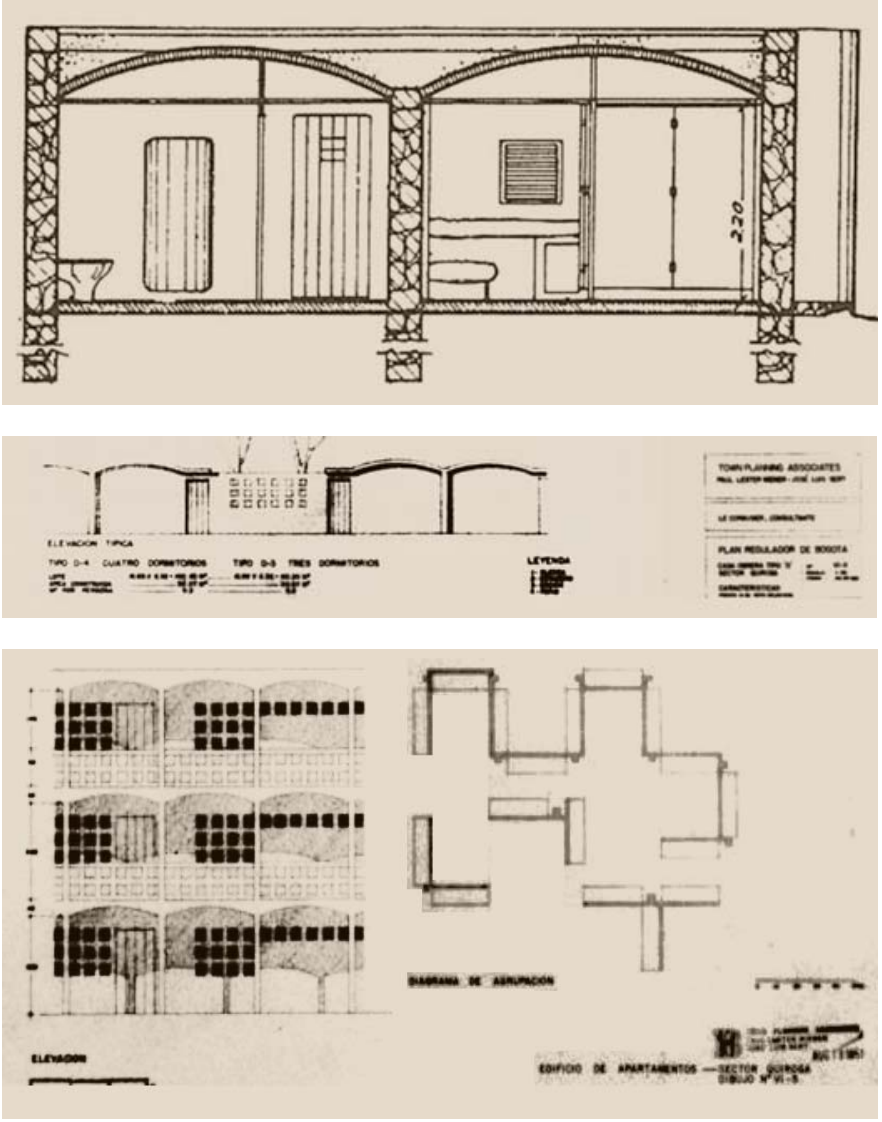

Figure 5A. Construction section of the Casas Garraf (Sert 1935). Figure 5B. Vaulted one-story houses for the Regulatory Plan of Bogotá (Sert and Wiener 1951). Figure 5C. Vaulted block of flats for the Regulatory Plan of Bogotá (Sert and Wiener 1951). All from The J.L. Sert Collection. Harvard.

A direct influence could be that of José Luis Sert, who since the late 40s developed, together with Paul Lester Wiener (Hernández 2017), various urban plans in Colombia, including several phases of the Bogota Regulatory Plan, in which Pizano actively collaborated (O'Byrne 2003). The vaulted houses that Sert proposed (through his company Town Planning Associates, active from 1941 to 1958, occasionally in collaboration with Le Corbusier) for Chimbote, Medellín or the Bogota neighborhood of Quiroga were designed (Tarchópolis 2012) to be covered with vacuum concrete vaults; nevertheless, the similarities between these proposals and the Casas Garraf (Mannino 1983) (Fig. 5A), where Sert used tile vaults in 1935, are evident. The Casas Garraf had been published on the cover of AC magazine (number 19), a GATEPAC publication that was a confessed inspiration for PROA magazine, the communication apparatus of Colombian architectonic modernity. The Casas Garraf are probably the first antecedent of modern recycling of tile vaults, and incorporated almost all the invariants that will reappear in most of the buildings that will be mentioned hereinafter: tile vaults of two or three layers, with simple geometries, covered with hydrofuged mortars outside, with concrete beams and steel tension rods to alleviate the thrust of the masonry vaults, ventilation in the gables, etc. 
There are no constructive details of the Sert and Wiener's projects for the Quiroga neighbourhood (Hernández 2017) -as is only logical for a development of a regulatory plan-, but it seems clear that they had several architectural typologies in mind (Figs. 5B and 5C). These proposed types might have been inspired by some Spanish buildings covered with tile vaults: Sert's own Casas Garraf, of course, in the case of one-story buildings; but also others such as Francisco Cabrero's Virgen del Pilar block (1948) (VVAA 1990) in the case of the proposals for blocks of flats. It is possible that Sert, although originally designing for Ortega's vacuum concrete system (Tarchópolis 2012), was also aware that Murtra worked in the area and had in mind the possibility of using tile vaults, at least partially, on the construction. As will be discussed later, the buildings of the Quiroga neighbourhood -and other annexed areaswere built respecting the vaulted geometry designed by Sert: vacuum concrete was extensively used there, but other different techniques also seem to have showed up.
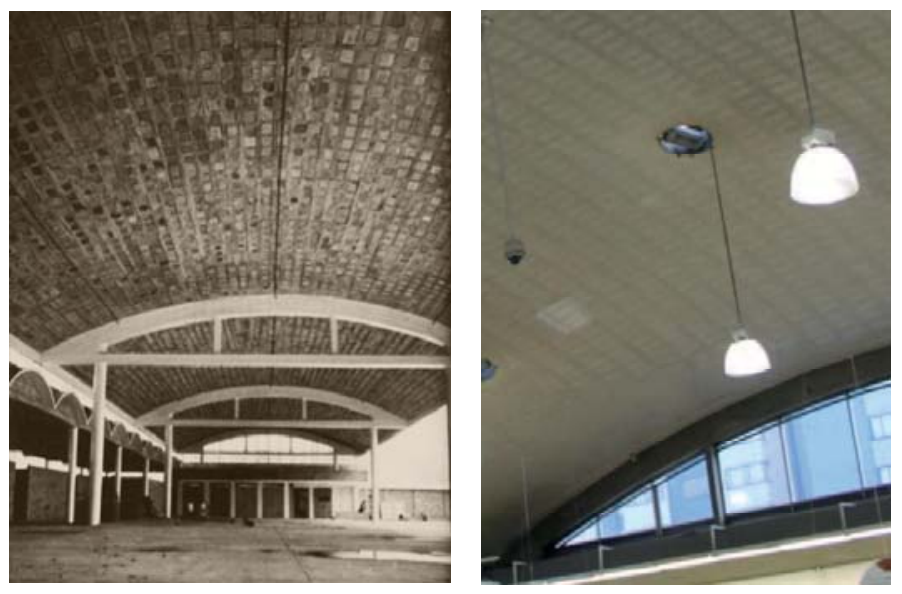

Figure 6A. Deck of the Bus Station of the C/ 68 in Bogotá (Solano, Ortega and G. Zuleta 1951). Figure 6B. Super Rayo Market (Pizano and G. Zuleta 1955). From Vargas (2015 and 2016).

The technical environment of Pizano might also have been decisive in his decision of using tile vaults to cover his house. At the end of the 40s and early 50s several Colombian architects and engineers used advanced laminar solutions on the roofs of large buildings (Vargas 2015; Escobar 2006). González Zuleta, for example, who had already built the Girardot market (1945) and the Cartagena stadium (1947) (Galindo 2016) with concrete shells, used brick vaults (Vargas 2008) in 1951 for the roof of the Bus Station of the C/68 in Bogotá (Solano, Ortega and G. Zuleta) (Fig. 6A). Zuleta would later collaborate with Pizano on other buildings covered with vacuum concrete vaults, such as the Clark Chiclets Factory (1953), or with reinforced ceramics, such as the Super Rayo Market (1954) (Fig. 6B) (Vargas 2016). The influence of this engineer on the construction of civil works has already been studied
(Galindo 2017), but not so much in regard to housing and small buildings. In any case, it is likely that, out of simple nearness, Zuleta was influential in decisions such as the one Pizano made when he decided to use tile vaults to cover a complete building.

Influences might also come from other engineers (see González 2016) or from vaults in buildings from other countries. Many tile vaults were used, for instance, for small-scale buildings in the Spanish post-civil war period, such as the Casas Usera (Moya 1942) or the reconstruction of Villanueva de la Cañada (Castañón and Fungairiño 1942). However, it seems complicated that Pizano knew about this background: the diffusion of these buildings, through the "Reconstruction" magazine, was very limited.

\section{INFLUENCE OF THE VAULTS OF THE CASA PIZANO IN COLOMBIA}

Casa Pizano had a great influence on the Colombian architecture of the 50s; but the tile vaults that Pizano used did not take root (Samper 2000). Only a few buildings designed or covered with these vaults can be traced. One example is the group of Casas Retiro (Figs 7A and 7B), designed by Pizano, Bermúdez and Viecco. The authors wrote about this building in PROA: "For one of those clients without prejudice, this group of houses is being built. Observe the simple masonry in brick studied with load-bearing walls; the condensed distribution in two and half floors [...]; the mezzanines and the roof with brick vaults resting on concrete beams and the pleasant and sober exterior presentation obtained with simple elements of which some will be pre-moulded" (PROA No. 44, 1951). The vaults that are detailed in the sections are of two brick layers, clearly covered with mortar at the top.
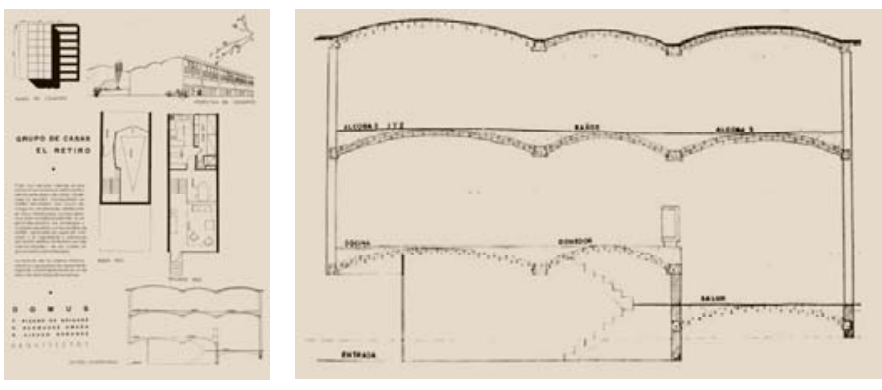

Figure 7A. Group of Casas Retiro (Pizano, Bermúdez and Viecco). Figure 7B. Sections of the several double layer tile vaults of the project, with fillings in the mezzanine and hydrofuged mortar layer as external cover. Both from PROA no 44.

Another interesting case is that of the 1970 Economic Houses of the Urdaneta Arbeláez neighborhood (García and Moreno 1953) (Jaimes 2008). Integrated in the Quiroga neighborhood plan and formed by "minimum houses in number of 400 with a built area of $33 \mathrm{~m} 2$ [...] average houses in number 
of 1026 [...] with 50 and $54 \mathrm{~m} 2$ of construction [...] and large houses in number of 292 with [...] a built area of $75 \mathrm{~m} 2 "$, the neighborhood was entirely covered, following the model of Sert for Quiroga, with vaulted structures (Fig. 8A). As described in PROA, this time several types of construction systems were used, without discarding the tile vaults: "the contractors, young architects, have used here several procedures: the Catalan system with rectangular ceramic 'locetas' ('rasilla' brick) and a simple formwork, the concrete vault poured directly on a timber formwork and the prefabricated system of the Vacuum Concrete company in Colombia" (Figs. 8B and 8C) (PROA No. 71, 1953) (Ortega 1989).
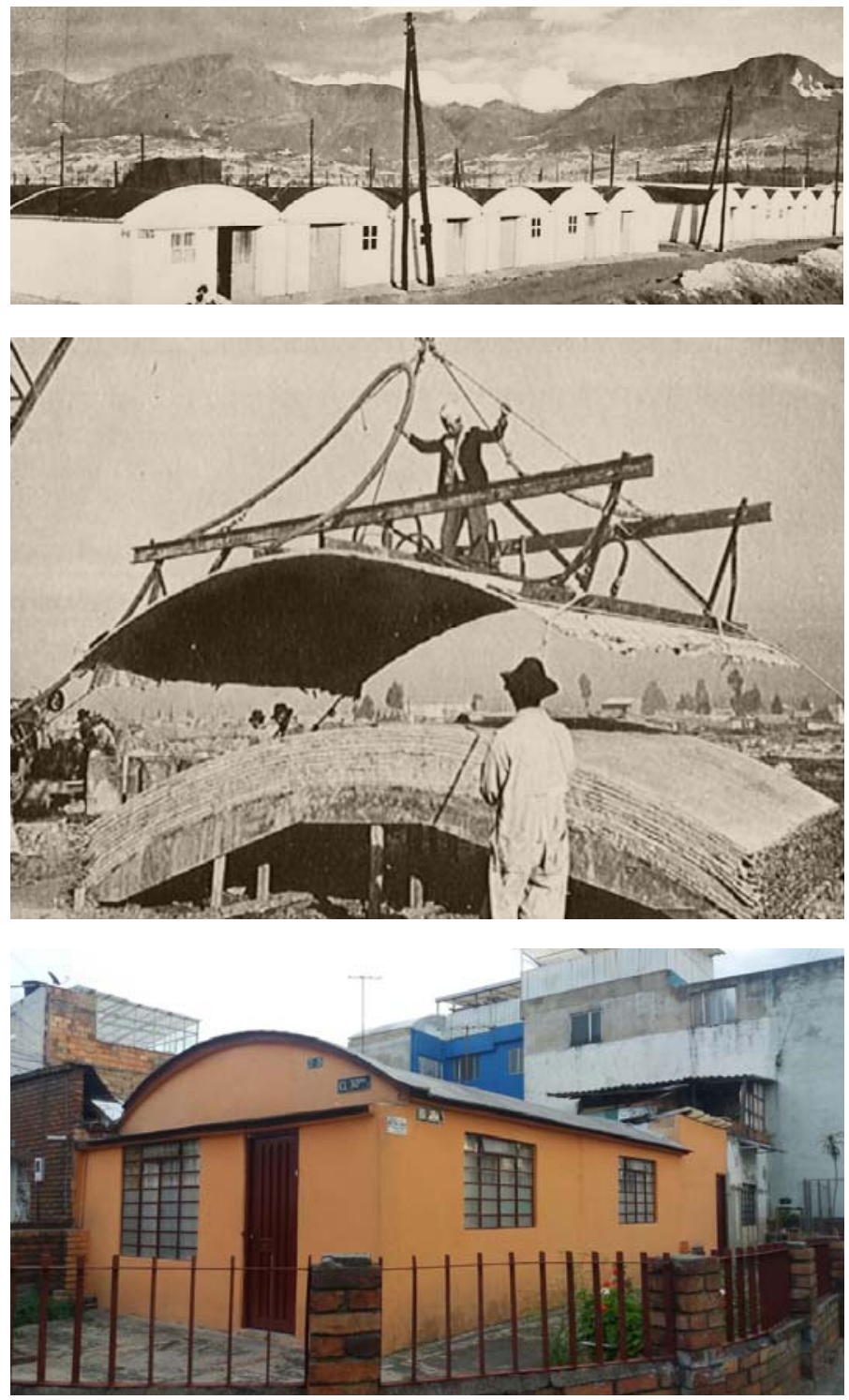

Figure 8A. Set of Houses in the Urdaneta Arbeláez neighborhood, some of which were built with "the Catalan system, with rectangular ceramic locetas and a simple formwork". Figure 8B. Assembly of a precast vacuum concrete vault at the Quiroga neighborhood. Both from PROA $n^{\circ} 71$. Figure 8C. Current view of the Quiroga neighborhood. Photo: Juan M. Medina.

Some buildings were designed with tile vaults but finally built with other systems. This is the case of one of the most well-known and influential houses of modernity in Colombia (O'Byrne 2010), the Casa
Bermúdez-Samper. Built by Guillermo Bermúdez in the neighborhood of El Retiro in 1953 (in its first stage; it was later extended), the house resembled the Casa Pizano in some points, the most important ones being the use of tile vaults in the staircase and in the structure of floors and roofs, including those of a double floor area (García 2004) (Fig. 9A).
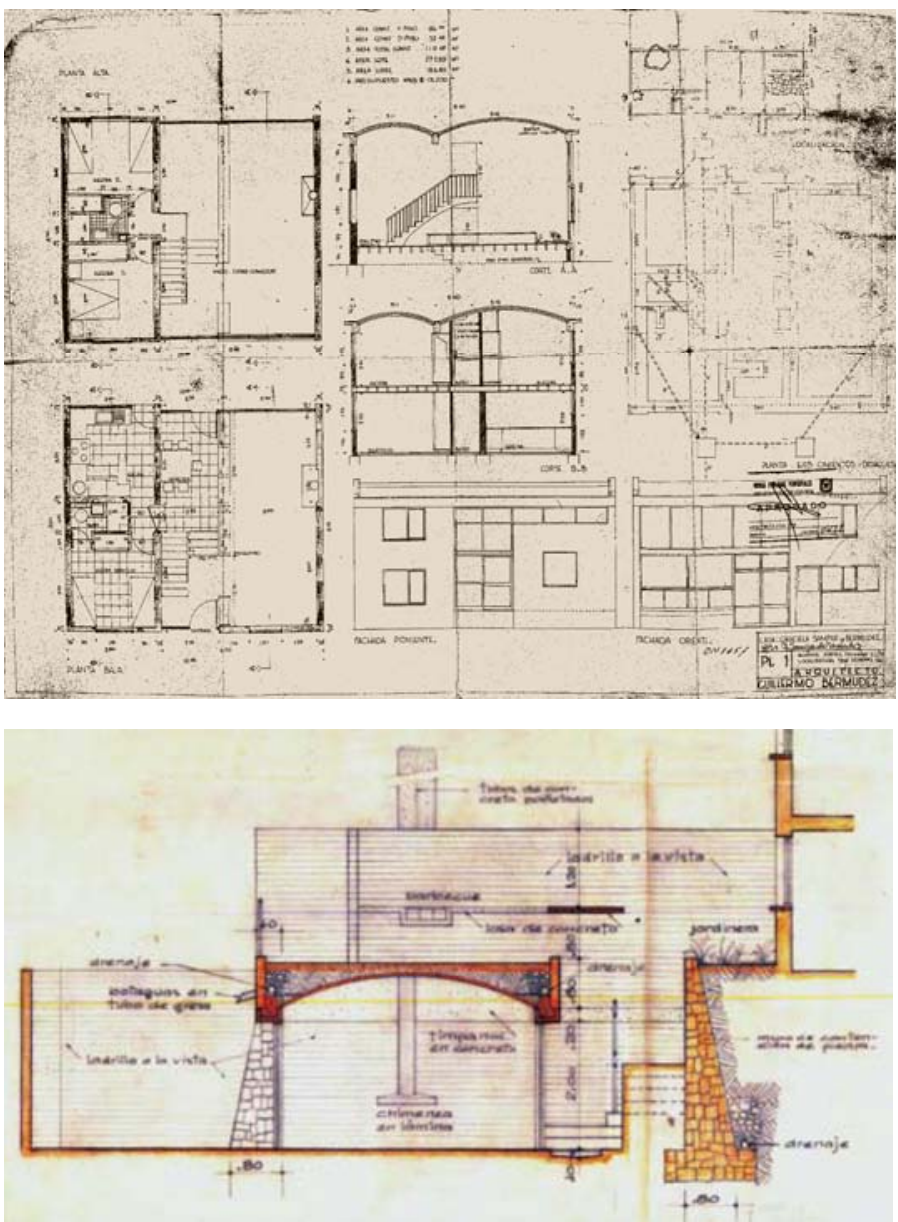

Figure 9A. Plans of Casa Bermúdez Samper (Bermúdez 1953). The Project included two-layer vaults in the structure of the roof and in the stairs. From O'Byrne 2010. Figure 9B. Sections of the Casa Celis' studio (Robledo, Drews and Castro 1956). From García 2009.

As O'Byrne points out "in the plan approved by the office of Municipal Public Works, the roof and the staircase are designed as Catalan vaults, in "tablón" brick, designed, according to plans that remain in the file of Guillermo Bermúdez, by his partner of then in several projects, the Colombian-Catalan engineer Fernando Murtra Casanovas. However, there is no study to explain how and why they decided to change the construction system, using the vacuum concrete system, used by Ortega and Solano in several neighbourhoods built for ICT" (O'Byrne 2010). In fact, the Casa Bermúdez-Samper was built with vacuum concrete shells. There is no record of the changes that this modification should have implied in the relationship between the new vault and the rest of the constructive elements.

Tile vaults were also used, in several occasions, not for the main structure of a complete building but 
for partial spaces, such as basements or overlays. An interesting example is that of the Casa Celis (Robledo, Drews and Castro 1956). Robledo described the area of the study as "a thrust vault built with tiles ("rasilla") over loadbearing walls built with Stone while the dividing walls are in face brick" (García 2009). The configuration is that of the usual segmental tile vault, with a span/rise ratio of approximately $1 / 10$, resting on concrete cable-stayed beams (Fig. 9B).

Tile vaults were gradually abandoned, but maintained their usefulness in the construction of elements of small size but high formal complexity, such as verandas or staircases. It is difficult to trace this type of construction, except in the case of representative buildings; Hernando Vargas Caicedo mentions, as an example of a large-scale staircase built with this technique, the case of the imperial stairs of the National Museum of Colombia in Bogotá, a building readapted in 1948 by Manuel de Vengoechea and Hernando Vargas Rubiano, also with the collaboration of Fernando Murtra.

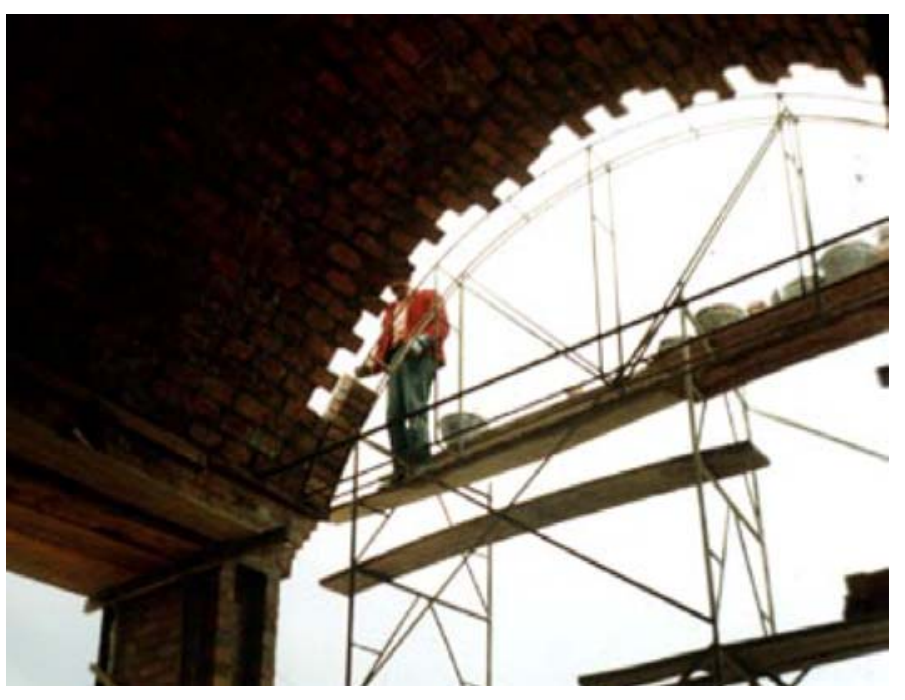

Figure 10. Construction of the Estacion La Caro tile vaults (Baresch 1985). From VVAA 2005.

The connection of these Colombian buildings of the 1950s with later experiences, such as the vaults of Rogelio Salmona (House of Guests 1978, Casa Tenjo 1989, Casa Cota 1995) (Adell 2005) or Herbert Baresch (Casas La Floresta I and II 1982, Estación La Caro 1985 (Fig. 10)) (VVAA 2005) is complex. Salmona worked in Le Corbusier's studio, and developed several vaulted buildings. In an interview in 2003 he declared that "yes, of those houses [Sarabhai and Jaoul] I did practically all the drawings but what influenced me most strongly was a Catalan architect, Scorza, that Le Corbusier brought to the studio to explain the tradition of the Catalan vault. He took me as an assistant, I went to Béziers with him and there he explained to me how the vaults were made, and I thought it was very interesting. On the other hand, I had already made a certain number of trips in Spain and Africa and that had given me some knowledge of the Saracen and Catalan vault" (Chaslin 2014).

Salmona had, therefore, a splendid knowledge of the system, acquired in the 50s; however, until the 1980s, neither he nor Baresch, each in his own way, used this form of construction again. It looks like that what might have propitiated the use of brick vaults in their buildings was a new environmental awareness (VVAA 2005), something that was not yet a fundamental concern in the times in which the Casa Pizano was built.

\section{INFLUENCE OF THE VAULTS OF THE CASA PIZANO IN LATIN AMERICA}

The influence of the Casa Pizano in the Latin American context is difficult to trace, given the distortion caused by the impact of the Maisons Sarabhai and Jaoul and the Bonet buildings, especially the Casa Berlingieri. These buildings were quite influential (Petrina 1989) but other reasons (García 2012) might also have had importance in the spreading of tile vaults in the following decades throughout Latin America. Many of them have remarkable similarities with Casa Pizano.

A very interesting example is that of the northern area of Argentina, and particularly the provinces of Salta and Tucumán. In that region, several architects linked to the Institute of Architecture and Urbanism of the University of Tucumán put into practice an architecture that was very similar to that of the Casa Pizano. They usually built isolated houses of one or two floors, modulated in successive parallel vaulted bays, so that each vault could take the thrusts generated by the ones at its right and left; for the lateral vaults, stability was achieved by steel bracing rods. The vaults were resting on concrete beams, and these on thick parallel masonry walls, lightened by concrete lintels to allow bigger inner spaces. They were built on small sliding formworks, and covered, as Casa Pizano, with a layer of hydrofuged mortar outside. Many of these buildings were collected by Eduardo Sacriste in "Viviendas con Bóvedas" (Sacriste 1977), a small handbook focused not only in the architectural planning of these houses, but also in the constructive technique used to build them.

The buildings collected by Sacriste in his handbook keep more similarities with Casa Pizano (or with the original project of Casa Bermúdez-Samper) than with Maisons Sarabhai, Jaoul, Casas Garraf or Casa Berlingieri. They all share, of course, some invariants: the face brick, the concrete beams connected with steel bracing or the ventilation in the timpanums (Fig. 11A). However, some Argentinian houses, such as Casa Wright (Goldman, Ramos and Erbin 1971) or Casa Larrán (Larrán 1965), are twostory buildings that simply show the vaults to the exterior, very much like the Colombian houses did, in a manner that allows direct water drainage -unlike 
what Le Corbusier designed for the Maison Sarabhai. Some others include stairs in two-story spaces (Fig. 11B); stairs that often allow crossing, as in Casa Pizano, from one to another vaulted bay (García 2014; García 2016) (Fig. 11C).
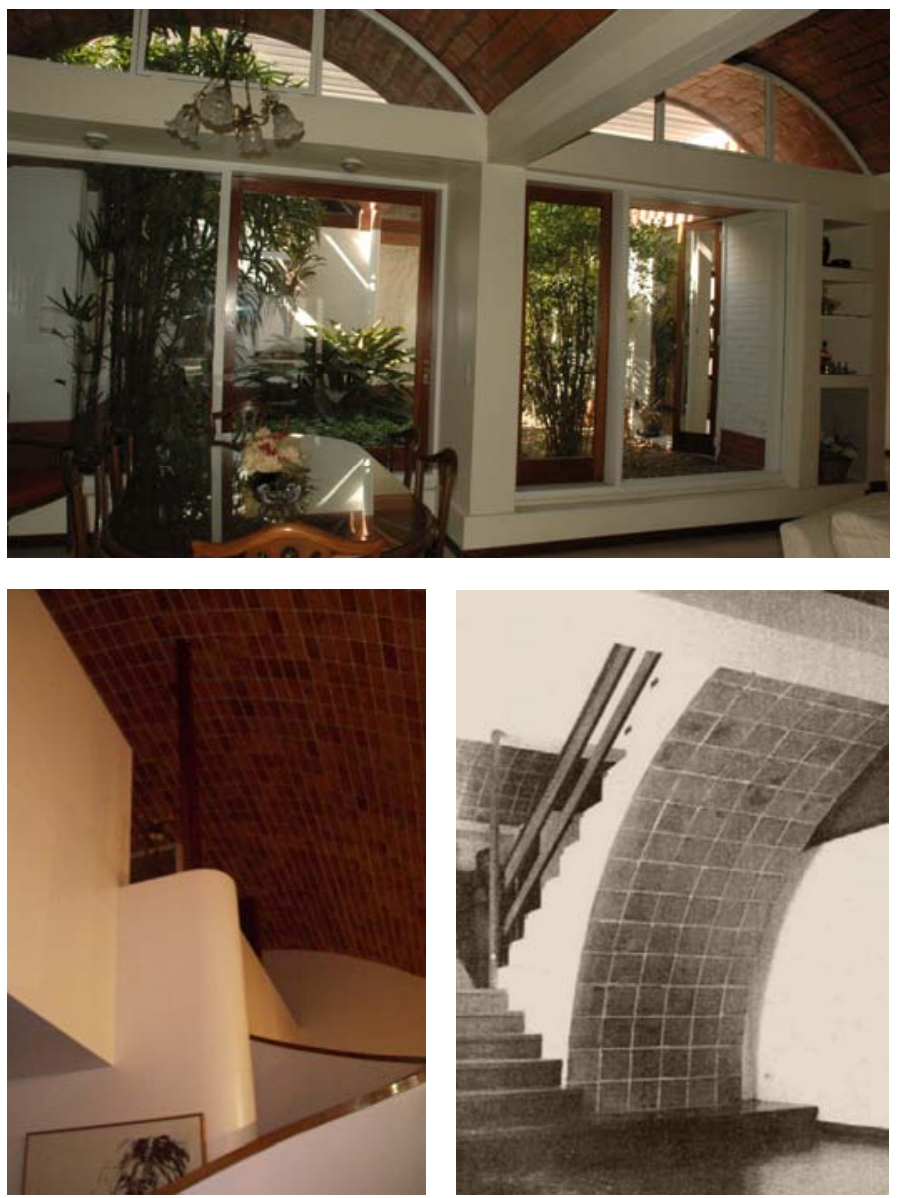

Figure 11A. Casa Iriarte (Coppens 1965). Photo: Analía Rondón. Figure 11B. Casa Wright (Goldman, Ramos and Erbin 1971). Interior. Photo: Candela Oliva. Figure 11C. Casa Clérico Hermanos (Sacriste 1958). A staircase in a two-story area. From Sacriste 1977.

Similar examples can be found in other areas of Latin America. Each region incorporates its own variants; Brazil (with the cases of Lefevre or Empire) (Fiori 2002), parabolic shapes or lightweight concrete slabs; Uruguay (Viera, Petit de la Villeon) (Loustau 1995), construction with reinforced masonry; Cuba, the experience of the Art Schools of Havana (Loomis 1999); Mexico, its own and splendid tradition of vault construction without formwork.

With regard to the routes through which these influences could occur, the extraordinary mobility of architects and builders at that time must be emphasized (Álvarez 2009, Bulnes, 2009, Botti 2017). It was not only Le Corbusier; Sert, Bonet and many others worked in several different countries in those years. Regarding the relationship between Argentina and Colombia in the 50s, several architects and professionals of the construction sector could have been important. The Argentinean Eduardo Catalano (professor at the MIT and author, among other works, of the well-known paraboloid of the Raleigh House -or Catalano- in the USA, together with $\mathrm{H}$. Caminos) invited Ortega (Correspondence Ortega / Catalano / Breuer, 1948; Breuer Archives) to participate in the urban planning of Buenos Aires, where he met the promoters of the then incipient Institute of Architecture of Tucumán (Sacriste, Vivanco and Caminos). Other characters link both countries through vault constructions, such as the Spaniard Ricardo Ribas Seva, who collaborated with Bonet on different projects in Argentina (Álvarez 2007) and is also the author of several projects in Bogotá, including the vault of the old Teatro Tesauquillo -nowadays Teatro Metro.

This mobility led to a certain sense of community among some architects of the subcontinent, a relationship that can be perceived not only in the mentioned projects but also in other initiatives, some of which can be traced today. One of the most interesting ones is that of the SomoSur collection, a set of books published by Editorial Escala, whose board of directors included, among others, Dieste and Ortega. SomoSur devoted several books to most of the architects mentioned in this article, such as Rogelio Salmona. One of the most interesting numbers was devoted to the Argentinian postmodern architecture, "Another Argentine architecture - An alternative path" (Gutiérrez 1989), and included an interview with Eduardo Sacriste (Petrina 1989) or precise descriptions of vaulted buildings such as Casa Soldati (Molinos 1962), also heir to the proposals of Pizano.

\section{CONCLUSIONS}

The shadow of the large buildings designed by Dieste or González Zuleta often hides other buildings of smaller scale but of equal or greater importance. The Casa Pizano, and some other vaulted houses built in the 1950s in Bogota, are good examples of these hidden constructions; buildings that exerted, through the interposed way of the famous Maisons Sarabhai and Jaoul or through the direct route of the relationships between Latin American architects and engineers, great influence in later constructions.

To this problem of scale another problem adds up: that of the visibility of the constructive system. Official historiography tends to attribute to reinforced ceramics a status of independent technique, oblivious to any other system close in time, and to Eladio Dieste a role as a lonely pioneer. Nothing of this is true. Dieste's role was fundamental, but his innovations arose in a context of multiple technical experimentations, always interconnected. The recycling of the tile vault, carried out by Pizano and many other architects throughout Latin America, was fundamental in the effervescence of structural solutions that arose at that time. 


\section{REFERENCES}

Adell, J. M. (2005) Rogelio Salmona y la arquitectura con ladrillo en Colombia. Informes de la Construcción, Vol 56, No 495. Madrid. DOI: 10.3989/ic.2005.v57.i495.456

Álvarez, F. (2007) "El exilio español en el cono sur”, in AA.VV. (Vicente, H. ed.); Arquitecturas Desplazadas. Arquitecturas del exilio español. Ministerio de Vivienda. Madrid.

Álvarez, F. (2009) “Relaciones entre el exilio catalán y el quehacer arquitectónico en Argentina, Uruguay y Chile (19391963)" in AA.VV. (Vicente, H. ed.); Presencia de las migraciones europeas en la arquitectura latinoamericana del siglo XX. UNAM. México.

Arango, S. (1989) Historia de la arquitectura en Colombia. Centro Editorial y Facultad de Artes, UNAL, Bogotá.

Arnaldos, A. (2014) Antonio Bonet Castellana, Le Corbusier y la bóveda catalana: forma y orden. Revista Dearq 14. pp. 122-135. Julio de 2014. Bogotá.

Botti, G. (2017) Geographies for Another History: Mapping the International Education of Architects from Colombia (1930-1970). Architectural Histories, 5(1): 7, pp. 1-35, DOI: $10.5334 /$ ah.230

Bulnes, L. \& Escobar, A. (2009) "Cinco arquitectos del exilio español en Colombia”, in AA.VV. (Vicente, H. ed.) Presencia de las migraciones europeas en la arquitectura latinoamericana del siglo XX. UNAM. México.

Chaslin, F. (2014) “Entrevista a Rogelio Salmona”, in Urrea, T. De la Calle a la Alfombra. Un espacio abierto en Bogotá. pp. 538-552. Universidad Politécnica de Cataluña. Barcelona.

Corradine, A. \& de Mora, H. (2001) Historia de la arquitectura colombiana. Vol. S.XIX. Universidad Nacional de Colombia.

Escobar, A. et al. (2006) "Hitos y protagonistas", in La construcción del concreto en Colombia. Asociación Colombiana de Productores de Concreto. Ed. Panamericana. Bogotá.

Fiori, P. (2002) Arquitetura Nova. Editora 34. Sao Paulo.

Galindo, J. et al. (2016) Geometry and Construction at Cartagena de Indias Baseball Stadium's Thin Shell Roofs (Colombia, 1947) Nexus Network Journal · December 2016. DOI: $10.1007 / \mathrm{s} 00004-016-0321-9$

Galindo, J. et al. (2017) Cáscaras de hormigón en la arquitectura colombiana del siglo XX: un caso de hibridación y asimilación tecnológica. Actas del X Congreso Nacional y II Internacional de Historia de la Construcción-San Sebastián. Instituto Juan de Herrera, Madrid.

García, F.E. (2004) "La vivienda de Guillermo Bermúdez: la arquitectura moderna en Colombia”, in Revista M, num. 3. pp. 42-55. Universidad Santo Tomás. Bucaramanga.

García, B. (2010) Arturo Robledo. La arquitectura como modo de vida. Instituto Distrital de Patrimonio Cultural. Universidad Nacional de Colombia. Bogotá.

García, J. et al. (2012) Arquitectura y construcción tabicada en torno a Eduardo Sacriste. Informes de la Construcción Vol. 64, 525, 35-50, pp. 35-50. Enero-marzo. CSIC. Madrid.

García J. \& Beltrán, M.A. (2014) La prefabricación de bóvedas de ladrillo. Una utopía latinoamericana. Revista Indexada de Textos Académicos, nº 2. Oct. 2014. pp. 92-99. Madrid.

García, J. \& Magdalena, F. (2015) Equilibrium and Prefabrication. Prefabricated Brick Vaults in Latin America. Proceedings of the Fifth International Congress on Construction History. vol. 2 pp. 153-160. Chicago.

Gulli, R. (1999) "La huella de la construcción tabicada en la arquitectura de Le Corbusier" in Las bóvedas de Guastavino en América, 87-112. Instituto Juan de Herrera. Madrid.
Gutiérrez, R. (2002) “Conversación con Francisco Pizano”, in Colección conversaciones de Arquitectura Colombiana, $\mathrm{n}^{\circ}$ 6, Nov. 2002, pp 97-119. Ediciones Uniandes. Bogotá.

Gutiérrez, R. et al. (1989) Otra arquitectura argentina - Un camino alternativo. Escala. Bogotá.

Hernández, C.E. (2017) De Le Corbusier a Sert en el Plan Director de Bogotá 1947-1953. Tesis no publicada. Universidad Nacional de Colombia. Bogotá.

Jaimes, S. (2008) “Concurso de viviendas económicas para empleados: un proyecto moderno en Colombia”, in Revista $M$ vol. 5 n 2 pp.84-97. Universidad Santo Tomás Bucaramanga.

Loomis, J.A. (1999) Revolution of Forms. Cuba's Forgotten Art Schools. Princeton, NY.

López, E. (2015) La mediterraneidad en la obra de Le Corbusier. La bóveda catalana lecorbuseriana: Influencias y evolución. Proceedings of Le Corbusier, 50 years later. UPV. Valencia. DOI: 10.4995/LC2015.2015.527.

López, D. et al.(2016) Dieste, González Zuleta and Sánchez del Río: Three approaches to reinforced-brick shell structures Structural Analysis of Historical Constructions -Van Balen \& Verstrynge (Eds)

Loustau, C.J. (1995) Influencia de Francia en la Arquitectura de Uruguay. Editorial Trilce. Montevideo.

Mannino, E \& Paricio, I. (1983) J. Ll. Sert. Construcción y arquitectura. Gustavo Gili. Barcelona.

O’Byrne, M. (2003) “Apuntes sobre el centro cívico del plan director de Le Corbusier para Bogotá”, in Revista en Blanco num. 12 Arquitectura Colombiana pp 6-12. Bogotá.

O’Byrne, M. (2010) “La casa Bermúdez-Samper, 1952-1960”, in Revista Dearq num. 07, pp. 66-81. UniAndes. Bogotá.

Ortega, Á 1989 Álvaro Ortega. Prearquitectura del bienestar. Escala. Bogotá.

Petrina, A. (1989) “Entrevista a Eduardo Sacriste”, in Gutiérrez, R. et al. Otra arquitectura argentina - Un camino alternativo. Escala. Bogotá.

Rodríguez, J.L. (2008) "Memorias de los años 50. Conversación con Francisco Pizano” in Revista deArquitectura 03. 12/08, pp. 16-29. Bogotá.

Sacriste, E. et al. (1977) Casas con bóvedas. Espacio Editora. Buenos Aires.

Samper, E. (2000) Arquitectura Moderna en Colombia: época de oro. Diego Samper Ediciones, Bogotá.

Tarchópolis D. \& Ceballos, O. (2005) Patrones Urbanísticos y Arquitectónicos en la Vivienda Dirigida a Sectores de Bajos Ingresos en Bogotá. Editorial Pontificia Universidad Javeriana. Bogotá.

Tomlow, J. (1999) "La bóveda tabicada y el nacimiento de la cerámica armada" in Las bóvedas de Guastavino en América, 87-112. Instituto Juan de Herrera. Madrid.

Torres, M.; Delgadillo, H. \& Peñarete, A. (2012) “Obras en Bogotá”, in Fray Domingo de Petrés en el Reyno de Nueva Granada” pp. 52-104. Alcaldía Mayor de Bogotá. Bogotá.

Vargas, H. (2008) "El desarrollo de la edificación en concreto armado en Colombia: El caso de los pioneros Doménico Parma y Guillermo González Zuleta (1945-1985)”, in DeArquitectura num. 04, 2008, pp. 64-79. Bogotá.

Vargas, H. \& Galindo, J. (2015) The construction of thin concrete shell roofs in Colombia during the first half of the 20th Century: the works of Guillermo González Zuleta (1916-1995) Fifth International Congress on Construction History. Chicago.

Vargas, H. (2016) "Mercado Super Rayo”, in Revista Construcción Metálica, pp 62-67.

VV.AA. (1990) Francisco Cabrero. Arquitectos 118. Consejo Superior de Arquitectos de España. Madrid.

VV.AA. (2005) Herbert Baresch. El hombre y el arquitecto. Villegas Editores. Bogotá. 